Acta vet. scand. 1984, 25, 195-204.

From the Department of Internal Medicine I, Division of Parasitology, the Norwegian College of Veterinary Medicine, Oslo, Norway.

\title{
A LIGHT MICROSCOPIC COMPARISON OF THE CYSTS OF FOUR SPECIES OF SARCOCYSTIS INFECTING THE DOMESTIC REINDEER (RANGIFER TARANDUS) IN NORTHERN NORWAY
}

\author{
By \\ Bjфrn Gjerde
}

GJERDE, B.: A light microscopic comparison of the cysts of four species of Sarcocystis infecting the domestic reindeer (Rangifer tarandus) in northern Norway. Acta vet. scand. 1984, 25, 195-204. - Fresh preparations of micro-isolated sarcocysts from skeletal and cardiac muscle of 12 reindeer were examined by light microscopy. On the basis of cyst structure and cyst wall structure 4 Sarcocystis spp. could be differentiated. New names have been proposed for 2 previously unnamed Sarcocystis spp. of reindeer, and $S$. grueneri has been redefined.

S. rangiferi n. sp. had macroscopic cysts in skeletal muscle measuring $2106 \times 403 \mu \mathrm{m}$. The cyst wall protrusions were finger-like and measured $13.2 \times 6.7 \mu \mathrm{m}$. The cysts were surrounded by a layer of fibrillar material.

S. tarandi n. sp. had micro- to macroscopic cysts primarily in skeletal muscle, but a few cysts were found in the heart of one animal. In skeletal muscle the cysts measured $999 \times 75 \mu \mathrm{m}$; in the heart the cysts were shorter and wider. The cyst wall protrusions were fingerlike and measured $9.2 \times 2.2 \mu \mathrm{m}$.

S. grueneri had micro- to macroscopic cysts in cardiac muscle measuring $581 \times 137 \mu \mathrm{m}$. The cyst wall was thin and relatively smooth with no visible protrusions.

Sarcocystis sp. had micro- to macroscopic, slender cysts in skeletal muscle measuring $916 \times 64 \mu \mathrm{m}$. The cyst wall had tightly packed, short, knob-like protrusions. The cysts of this species were previously classified as cysts of S. grueneri.

cyst structure; cyst wall structure; intermediate host; S. grueneri; S. rangiferi n. sp.; S. tarandi n. sp.

In a previous paper (Gjerde \& Bratberg 1984) 3 types of sarcocysts were described from muscle tissue of domestic reindeer. The description was based on a light microscopic examination 
of a limited number of cysts in stained sections of skeletal and cardiac muscle. In the present paper a more detailed description of these 3 types of sarcocysts is given, based on a light microscopic examination of fresh preparations of micro-isolated cysts. The thin-walled type 3-cysts are further differentiated in accordance with their location and structure. New names are proposed for 2 previously unnamed species of Sarcocystis of reindeer.

\section{MATERIALS AND METHODS}

The heart and a sample of skeletal muscle (from the thorax and abdomen) from each of 12 domestic reindeer were obtained from abattoirs in Kautokeino and Karasjok in Finnmark county in northern Norway. Samples were collected from the carcasses of adult reindeer with macroscopically visible sarcocysts in their skeletal musculature. The muscle tissue was kept refrigerated and examined within 2-4 days after the time of slaughter.

The samples were examined both grossly and under a stereo microscope $(12.5-50 \times$ magnification). The sarcocysts were isolated from the muscle tissue by means of. a fine needle and transferred to a drop of physiological saline on a microscopic slide. A coverglass was then applied and the cysts examined under a light microscope $(35-1000 \times$ magnification $)$. The cysts that were isolated were chosen at random regardless of their size and shape. Cysts from all 12 animals were isolated and examined. Measurements were only performed on mature cysts, i.e. cysts containing predominantly cystozoites (merozoites). An ocular micrometer was used to measure the size (length $x$ maximum width, i.e. diameter) of the cysts, the cyst wall protrusions and the cystozoites, the last mentioned after the cysts had been ruptured by applying a little pressure to the coverglass.

A regression analysis was performed on the measurements of length and width of the cysts of each species to determine the relationship between these two parameters. The mean length to width ratio of each type of sarcocyst was calculated from the individual ratios of all the cysts measured.

\section{RESULTS}

Based on a light microscopic examination of fresh, microisolated cysts and their cystozoites, 4 types of sarcocysts can be described from reindeer. 
Description of Sarcocystis rangiferi n. sp. (Sarcocystis sp. with type 1-cysts)

The mature cysts of Sarcocystis rangiferi were macroscopic in size and were easily seen by gross examination of skeletal muscle. They were not found in cardiac muscle. The cysts varied somewhat in size and shape, but usually they were oblong and thick with a cigar-like shape (Fig. 1). The cysts measured on average $2106 \pm 682$ (836 to 4740$) \mu \mathrm{m}$ in length (the mean \pm the standard deviation), and $403 \pm 106$ (135 to 810 ) $\mu \mathrm{m}$ in width; $\mathrm{n}=240$. Their mean length to width ratio was 5.31. The sample regression of width on length showed that the width increased an average of $0.095 \mu \mathrm{m}$ per $\mu \mathrm{m}$ increase in length.

At lower magnifications the cysts appeared to have a very thick wall (Fig. 1). At higher magnifications this thick "wall" was seen to be due to protrusions of the cyst wall proper together with a layer of fibrillar material surrounding the cysts (Figs. 2 and 3). The tightly packed cyst wall protrusions were upright and finger-like, giving the cyst "wall" a cross-striated, palisadelike appearance. The protrusions measured on average 13.2 (11.1 to 16.0$) \mu \mathrm{m}$ in length and $6.7(4.2$ to 8.0$) \mu \mathrm{m}$ in width, tapering somewhat at the distal end.

The layer of fibrillar material contained structures resembling cell nuclei. The layer varied in thickness from a few $\mu \mathrm{m}$ to about $25 \mu \mathrm{m}$ between different cysts, but usually had a thickness of 10 to $15 \mu \mathrm{m}$. The fibrillar layer was intimately investing the cyst wall protrusions along most of the cyst. However, at the ends of some cysts there seemed to be a layer of amorphous material between the protrusions and the fibrillar layer (Fig. 3). The fibrillar layer was not lost during the isolation of the cysts from the surrounding muscle tissue.

The interior of the cysts was divided into chambers by rather conspicuous septa (Fig. 2). The chambers contained numerous banana-shaped cystozoites measuring on average 11.6 (10.4 to 13.0 $\mu \mathrm{m}$ in length and $3.7(2.9$ to 4.2$) \mu \mathrm{m}$ in width; $\mathrm{n}=40$ (Fig. 4).

Description of Sarcocystis tarandi n. sp. (Sarcocystis sp. with type 2-cysts)

The mature cysts of S. tarandi were micro- to macroscopic in size, i.e. they were not easily seen by gross examination. They 
were found in skeletal muscle of all 12 reindeer examined, but in the cardiac muscle of only 1 animal.

In skeletal muscle the cysts were slender, elongate and spindelshaped (Fig. 5). The cysts measured on average $999 \pm 383$ (450 to 2206 ) $\mu \mathrm{m}$ in length, and $75 \pm 33$ (40 to 255 ) $\mu \mathrm{m}$ in width; $\mathrm{n}=85$. Their mean length to width ratio was 14.08 . The sample regression of width on length showed that the width increased an average of $0.041 \mu \mathrm{m}$ per $\mu \mathrm{m}$ increase in length.

At lower magnifications the cysts appeared to have a thick, light wall (Fig. 5). At higher magnifications this thick "wall" was seen to be due to protrusions of the cyst wall proper (Figs. 6 and 7 ). The tightly packed protrusions were upright or slightly bending and finger-like, giving the cyst "wall" a striated appearance. The protrusions measured on average $9.2(7.3$ to 10.6$) \mu \mathrm{m}$ in length and 2.2 (1.6 to 2.9) $\mu \mathrm{m}$ in width. There was no layer of fibrillar material surrounding the cysts of this species.

The interior of the cysts was divided into chambers by thin septa (Fig. 6). The chambers were filled with banana-shaped cystozoites measuring on average 11.5 (9.7 to 13.0 ) $\mu \mathrm{m}$ in length and 3.2 (2.5 to 4.0 ) $\mu \mathrm{m}$ in width; $\mathrm{n}=40$ (Fig. 8).

The cysts of $\mathrm{S}$. tarandi occurring in the heart of one animal were shorter and wider than those found in skeletal muscle. Four cysts measured on average 353 (308 to 421) $\mu \mathrm{m}$ in length, and 116 ( 85 to 150 ) $\mu \mathrm{m}$ in width, with a mean length to width ratio of 3.2. The protrusions measured $10.2 \mu \mathrm{m}$ in length and $2.0 \mu \mathrm{m}$ in width and had the same outlook as the protrusions of the cysts in skeletal muscle.

Description of Sarcocystis sp. with type 3-cysts in skeletal muscle

The cysts of this species were found in skeletal muscle only. They were micro- to macroscopic in size, and were slender, elongate and spindelshaped (Fig. 9). The cysts measured on average $916 \pm 269$ (450 to 1415 ) $\mu \mathrm{m}$ in length, and $64 \pm 21$ (40 to 135) $\mu \mathrm{m}$ in width; $n=46$. Their mean length to width ratio was 15.00. The sample regression of width on length showed that the width increased an average of $0.029 \mu \mathrm{m}$ per $\mu \mathrm{m}$ increase in length.

The cyst wall had tightly packed, short (less than $1 \mu \mathrm{m}$ ), knob-like protrusions (Figs. 10 and 11), giving the cyst outline an indented appearance. The protrusions could be seen at 

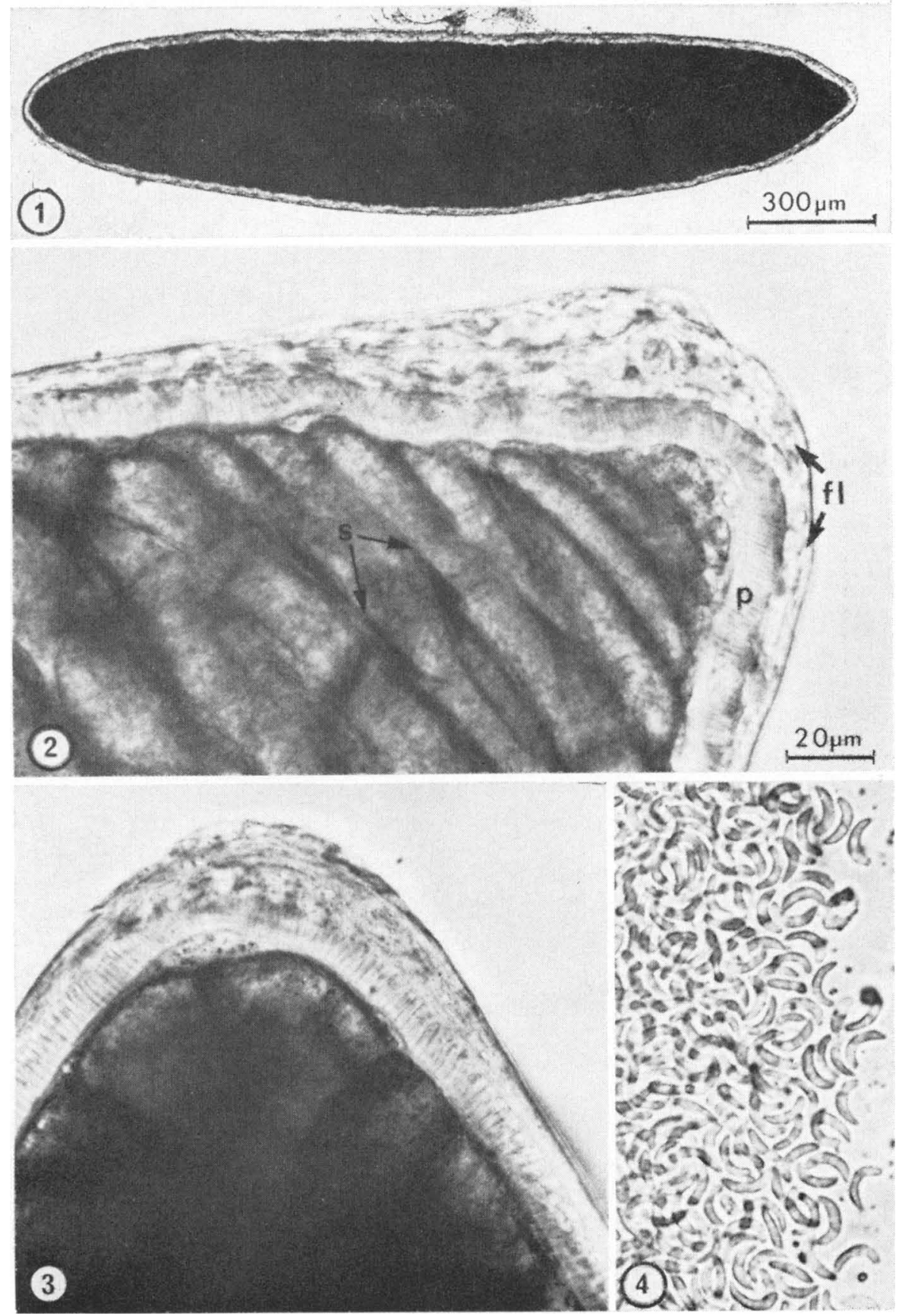

F i g u r e s 1-4. Sarcocystis rangiferi n. sp.; fresh preparations of cysts and cystozoites.

F i g u r e 1. Micro-isolated cyst of S. rangiferi. Note long, wide cyst with thick "wall". $\times 68$.

F i g u r e 2. Part of cyst. Note conspicuous septa (s), cyst wall protrusions (p) and fibrillar layer (fl). $\times 680$.

F i g u re 3. Part of cyst. Note finger-like protrusions and fibrillar layer. $\times 680$.

F i g u r e 4. Cystozoites of S. rangiferi. $\times 680$. 

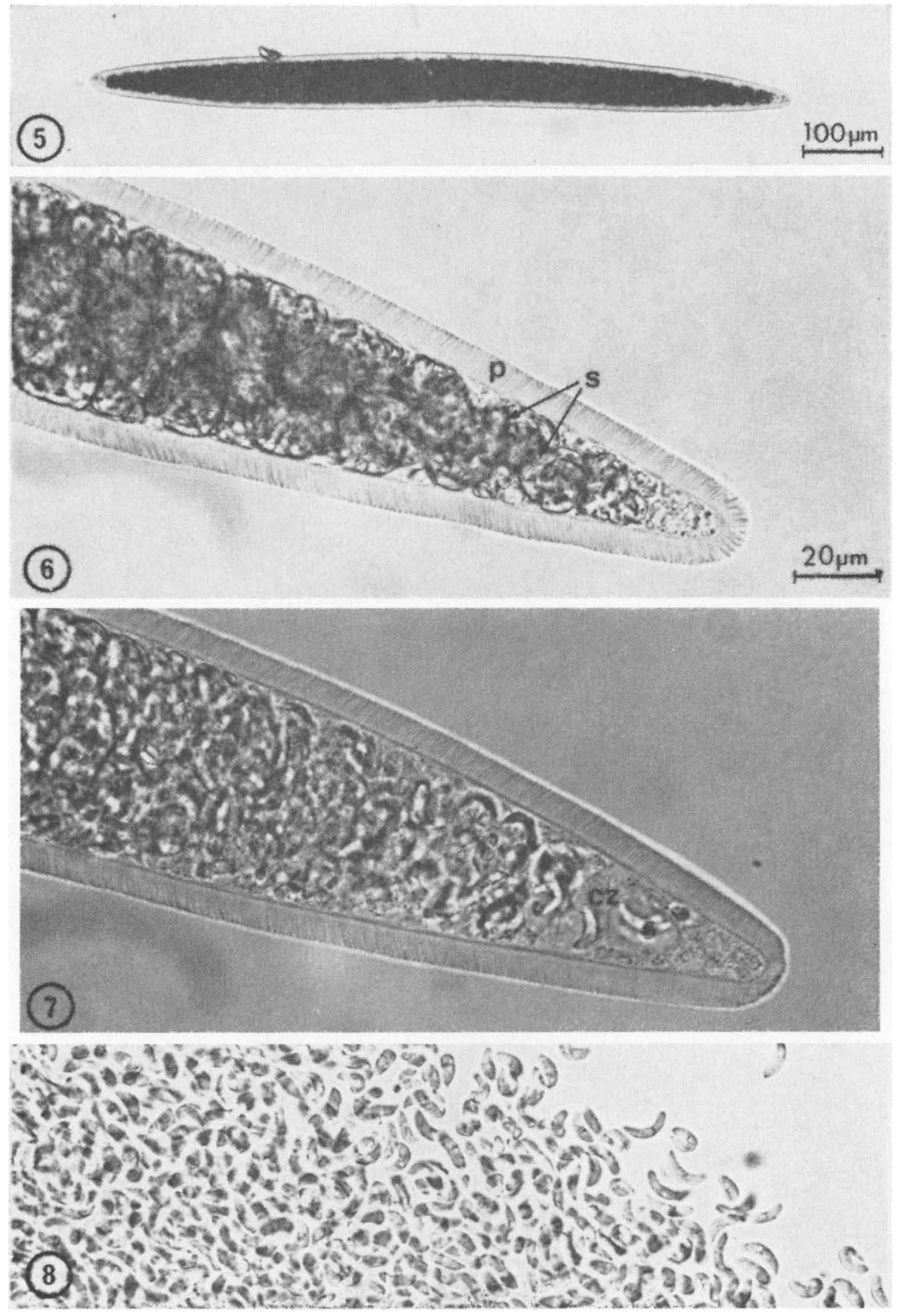

Figures 5-8. Sarcocystis tarandi n. sp.; fresh preparations of cysts and cystozoites.

F i g u r e 5. Micro-isolated cyst of S. tarandi. Note slender, spindelshaped cyst with a thick "wall". $\times 127.5$.

F i g u r e 6. Part of cyst. Note slightly bending, finger-like cyst wall protrusions $(\mathrm{p})$ and thin septa $(\mathrm{s}) . \times 680$.

F i g u r e 7. Part of cyst. Note cystozoites (cz) within cyst. $\times 680$.

Figure 8. Cystozoites of S. tarandi. $\times 680$. 


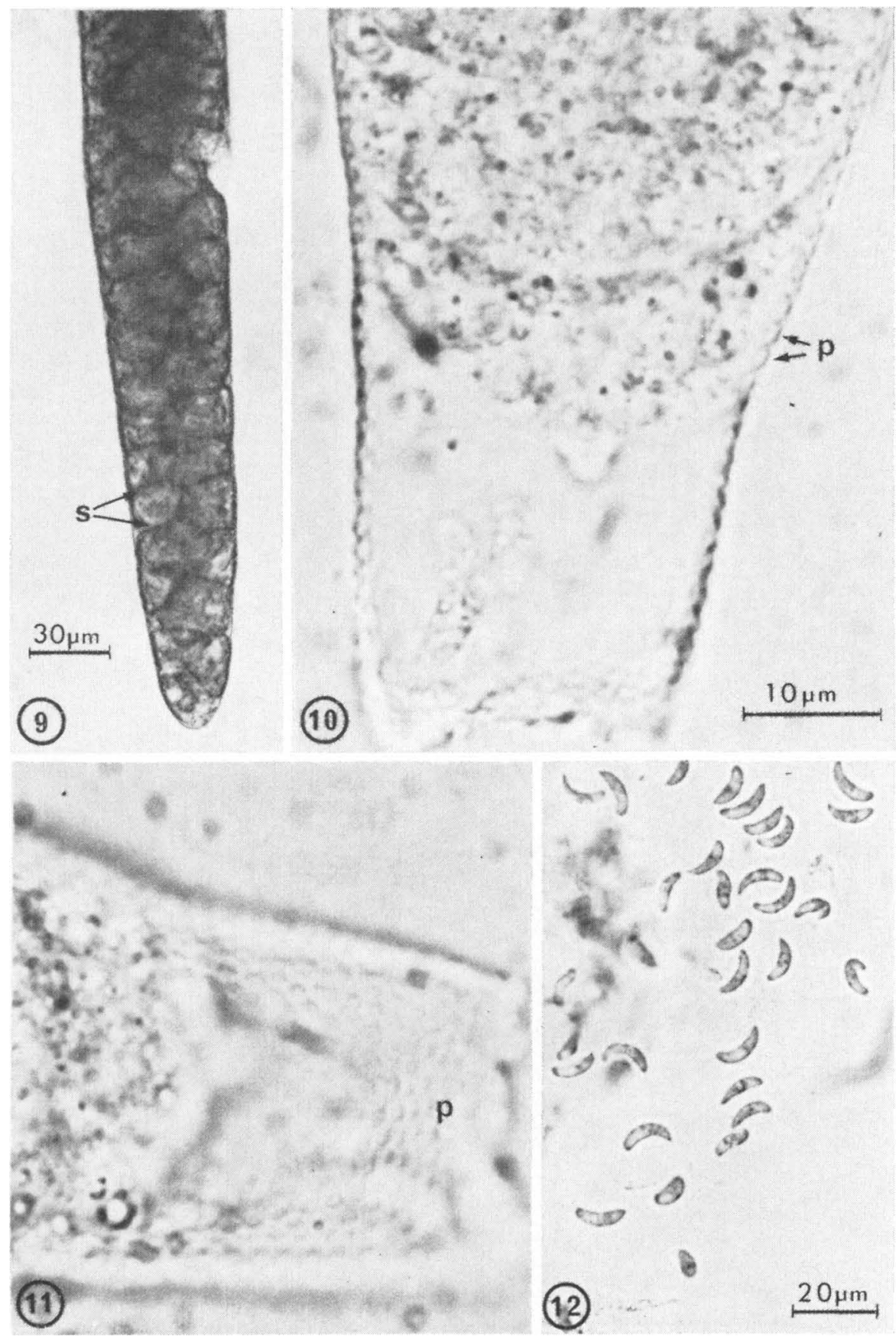

F i g u res 9-12. Sarcocystis sp. in skeletal muscle; fresh preparations of cysts and cystozoites.

F i g u r e 9. Part of micro-isolated cyst. Note slender cyst with thin wall and thin septa $(\mathrm{s}) . \times 425$.

Figure 10. Part of cyst where the contents have been displaced. Note indented cyst wall due to short, knob-like protrusions (p). $\times 2125$.

F i g u r e 11. Same cyst as in Fig. 10 in a different plane of focus. Note knob-like protrusions. $\times 2125$.

Figure 12 . Cystozoites of Sarcocystis sp. $\times 680$. 

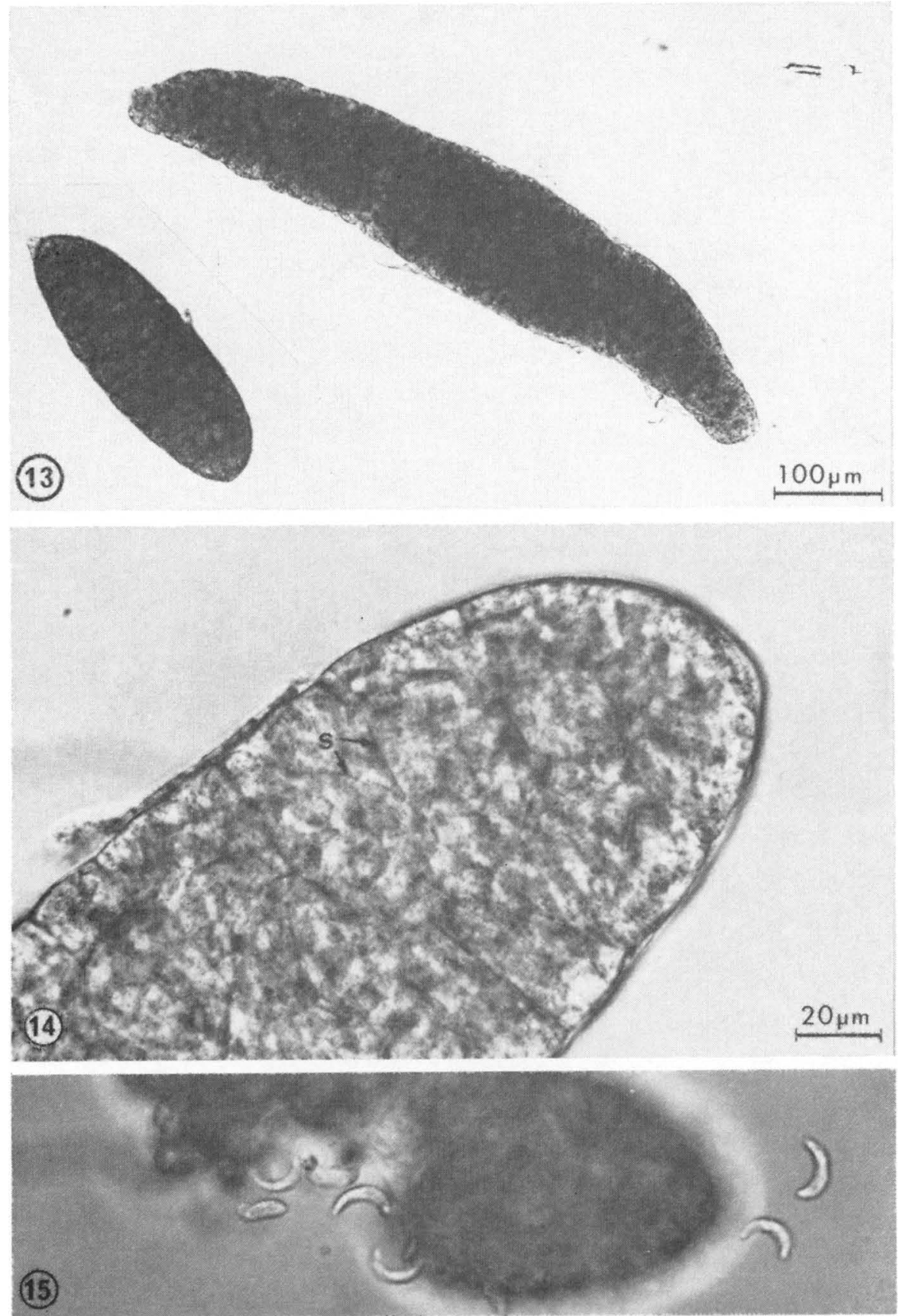

F i g u res 1 3-15. Sarcocystis grueneri in cardiac muscle; fresh preparations of cysts and cystozoites.

Fig u r e 13. Two micro-isolated cysts. Note difference in size and shape - between the cysts. $\times 170$.

Figu r e 14. Part of the smaller cyst in Fig. 13. Note thin cyst wall and thin septa $(\mathrm{s}) . \times 680$.

F i g u r e 15. Cystozoites of S. grueneri. $\times 680$. 
magnifications of $200 \times$ and higher, but could easily be overlooked by inadequate focusing.

The interior of the cysts was divided into chambers by thin septa (Fig. 9). The chambers were filled with banana-shaped cystozoites (Fig. 12) measuring on average 13.8 (12.6 to 15.0) $\mu \mathrm{m}$ in length, and 4.0 (3.3 to 4.8 ) $\mu \mathrm{m}$ in width; $\mathrm{n}=40$.

Description of Sarcocystis grueneri (Sarcocystis sp. with type 3-cysts in cardiac muscle)

The cysts of S. grueneri were micro- to macroscopic in size and occurred in cardiac muscle only. Cysts of this species were found in all 12 hearts examined, and in 11 of them it was the only species found. The cysts varied considerably in size and shape (Fig. 13), but usually they were oblong and rather thick with rounded ends. The cysts measured on average $581 \pm 175$ (240 to 1160$) \mu \mathrm{m}$ in length, and $137 \pm 59$ (45 to 325$) \mu \mathrm{m}$ in width; $n=204$. Their mean length to width ratio was 4.57 . The sample regression of width on length showed that the width increased an average of $0.225 \mu \mathrm{m}$ per $\mu \mathrm{m}$ increase in length.

The cyst wall was thin and relatively smooth with no visible protrusions. The cyst outline showed a slight undulation due to rather deep invaginations of the cyst wall at the origin of the septa. The thin septa (Fig. 14) divided the interior of the cysts into numerous chambers containing tightly packed bananashaped cystozoites (Fig. 15) measuring on average 15.2 (13.9 to 16.5) $\mu \mathrm{m}$ in length, and 3.9 (2.4 to 4.8$) \mu \mathrm{m}$ in width; $\mathrm{n}=50$.

\section{DISCUSSION}

In the present investigation fresh preparations of micro-isolated sarcocysts were examined. When using a light microscope, this method reveals more of the microscopic structure of the cysts than a study of cysts in sections of muscle tissue. As sections only show two dimensions, it may be difficult to visualize the three-dimensional structure of the sarcocysts and the cyst wall protrusions. Furthermore, a single section cut through a cyst is only a thin slice of the cyst and may give an incorrect impression of the size and shape of the cyst. It all depends on how the section through the cyst is cut. For instance, only a longitudinal section cut through both ends of the cyst will give the true length of the cyst, while a longitudinal section cut at a different level 
or an oblique section will give the impression of a shorter cyst. Similarly, the measured width (diameter) of a cyst wille deviate more or less from the true maximum width of the cyst depending on the plane and level in which the slice of the cyst has been cut. When studying micro-isolated cysts there are no problems of this kind, and very reliable information on the size and shape of the sarcocysts and the cyst wall protrusions can be obtained.

It has been found (Erber 1977, Mehlhorn \& Heydorn 1978) that within a given species of intermediate host, the structure of the cyst wall of mature cysts is a reliable criterion for differentiating between cysts of different species of Sarcocystis. Furthermore, members of the genus Sarcocystis show a high degree of intermediate host specificity. The species described in the present paper can therefore be considered to be true reindeer species, i.e. with the reindeer as their natural intermediate host.

Previously, there has been only one named species of Sarcocystis from reindeer (Levine \& Tadros 1980). The name Sarcocystis grueneri was introduced by Yakimoff $\&$ Sokoloff (1934), but the descriptions of the species both in that paper and in a later paper by Yakimoff (1936) were incomplete. This was thoroughly discussed by Gjerde \& Bratberg (1984), who assigned the name $S$. grueneri to the species which they believed had thinwalled cysts (Type 3) in both cardiac and skeletal muscle.

The present investigation has shown, however, that the type 3-cysts occurring in skeletal muscle are different from those in cardiac muscle with regard to size and shape and cyst wall structure. While the cysts in skeletal muscle were relatively long, slender and spindelshaped, the cysts in cardiac muscle were rather short and thick. This difference may in part be due, however, to their different location and the structural difference between skeletal and cardiac muscle. Furthermore, the cysts in skeletal muscle possessed short, knob-like cyst wall protrusions, while the cysts in cardiac muscle appeared to be without protrusions. However, the difference in cyst wall structure was not very evident by light microscopy, and will have to be confirmed by an ultrastructural study of the cysts.

Nevertheless, the thin-walled type 3-cysts in cardiac and skeletal muscle, respectively, are considered to be cysts of 2 different species. Consequently, the species $\mathrm{S}$. grueneri will have to be redefined. As the original description of S. grueneri (Yakimoff $\&$ Sokoloff 1934) referred to findings in the heart, the name is 
assigned to the species with thin-walled cysts in cardiac muscle of reindeer. The species with thin-walled cysts in skeletal muscle is for the time being, not renamed.

S. grueneri, the only species usually infecting cardiac muscle, was found by Gjerde \& Bratberg (1984) to have the fox (and probably also the dog) as its definitive host, while any of the 3 other species could have caused the shedding of Sarcocystis sporocysts by foxes and dogs given skeletal muscle in their experiments. It is also possible that some of the thin-walled cysts in skeletal muscle really were cysts of $S$. grueneri according to the new definition, even though such a mixed infection has not been detected in the present investigation.

Many workers defer to name a new species of Sarcocystis until its life cycle has been completed in a definitive host. The reason for this is the wish to combine the name of the intermediate host and the name of the definitive host in the new species name, consistent with the proposal for a new nomenclature made by Heydorn et al. (1975). If not adopting this system of nomenclature, there is no need to defer the naming of a new species until its definitive host has been determined, provided that its cysts have been adequately described. In the present paper the new names S. rangiferi and S. tarandi have been proposed for the species with cysts of type 1 and type 2, respectively, in skeletal muscle of reindeer. Both names are derived from the latin name, Rangifer tarandus, of their intermediate host. So far, the definitive hosts of $S$. rangiferi and S. tarandi are unknown.

The cysts of $S$. rangiferi were surrounded by a layer of fibrillar material closely investing the protrusions. The origin and fine structure of this layer could not be determined by the methods employed in the present study. However, it is likely that this layer is of host cell origin, initially surrounding the host cell, but coming into close contact with the cyst wall protrusions as the cyst grows and fills the entire parasitized cell. The fibrillar layer surrounding the cysts of $\mathrm{S}$. rangiferi thus probably constitutes a secondary cyst wall as in S. gigantea of sheep (Bergmann \& Kinder 1975, Mehlhorn \& Heydorn 1978).

As the cysts of $\mathrm{S}$. rangiferi are easily seen by gross examination, it was probably mainly cysts of this species that were reported by Skjølaas (1970), and later by public reindeer meat inspectors. Poppe (1977), Rognerud (1978) and Korbi (1982) 
found macroscopic cysts in about $4 \%$ of all reindeer slaughtered, but with a much higher prevalence in older animals.

The cysts of $S$. tarandi had finger-like protrusions of the cyst wall like the cysts of $S$. rangiferi, but the protrusions were shorter and more slender $(9.2 \times 2.2 \mu \mathrm{m}$ v. $13.2 \times 6.7 \mu \mathrm{m})$ in the former species. Moreover, the cysts themselves were shorter and more slender $(999 \times 75 \mu \mathrm{m}$ v. $2106 \times 403 \mu \mathrm{m})$, and they were not surrounded by a fibrillar layer like the cysts of $S$. rangiferi. Thus, there are no difficulties in distinguishing between these two "thick-walled" species.

The cysts of S. tarandi and Sarcocystis sp. in skeletal muscle were of similar size and shape $(999 \times 75 \mu \mathrm{m}$ v. $916 \times 64 \mu \mathrm{m})$, making it impossible to distinguish between the two species by gross examination. However, by light microscopy the differences in their cyst wall structure (finger-like v. short, knob-like protrusions) made the species identification easy.

The size of the cystozoites is not considered to be a reliable criterion for differentiating between different species of Sarcocystis (Mehlhorn \& Heydorn 1978). However, the cystozoites of S. grueneri were found to be somewhat larger than those of the 3 other species, but relatively few cystozoites were measured.

The present description of the differences in cyst wall structure between the 4 species were based on a light microscopic study of the cysts. With the use of an electron microscope it is probable that more distinguishing features will be found for each of the 4 species. Further work is also required to elucidate the life cycle of these Sarcocystis spp. infecting the domestic reindeer in northern Norway.

\section{ACKNOWLEDGEMENTS}

The author would like to thank K. Korbi (Kautokeino) and $\mathrm{K}$. Bach-Gansmo (Karasjok) for sampling of the muscle tissue from reindeer, and H. Giltvedt and I. Catrinius at the Photographic Department, the Norwegian College of Veterinary Medicine, for doing most of the photographic work.

\section{REFERENCES}

Bergmann, V. \& E. Kinder: Unterschiede in der Struktur der Zystenwand bei Sarkozysten des Schafes. (Sarcocystis in sheep. Differences in cyst wall structure). Mh. Vet.-Med. 1975, 30, 945947. 
Erber, M.: Möglichkeiten des Nachweises und der Differenzierung von zwei Sarcocystis-Arten des Schweines. (Detection and differentiation of two Sorcocystis spp. in pigs). Berl. Münch. tierärztl. Wschr. 1977, 90, 480-482.

Gjerde, B. \& B. Bratberg: The domestic reindeer (Rangifer tarandus) from northern Norway as intermediate host for three species of Sarcocystis. Acta vet. scand. 1984, 25, 187-194.

Heydorn, A.-O., R. Gestrich, H. Mehlhorn \& M. Rommel: Proposal for a new nomenclature of the Sarcosporidia. Z. Parasitenk. 1975, $48,73-82$.

Korbi, K. A.: Sykdomsregistrering i reinkjøttkontrollen. (Parasitic diseases recorded in reindeer during meat inspection). Norsk Vet.-tidsskr. 1982, 94, 45-49.

Levine, N. D. \& W. Tadros: Named species and hosts of Sarcocystis (Protozoa: Apicomplexa: Sarcocystidae). Syst. Parasitol. 1980, $2,41-59$.

Mehlhorn, H. \& A.O. Heydorn: The Sarcosporidia (Protozoa, Sporozoa): Life cycle and fine structure. Adv. Parasitol. 1978, 16, 43-91.

Poppe, T. T.: Sykdomsregistrering hos rein ved den offentlige kjøttkontrollen i Kautokeino høsten og vinteren 1976/76. (Parasitic diseases recorded in reindeer during meat inspection in Kautokeino (Norway) in autumn and winter, 1976-77). Norsk Vet.tidsskr. 1977, 89, 791-795.

Rognerud, B.: Sykdomsregistrering hos rein ved den offentlige kjøttkontrollen i Kautokeino høsten og vinteren 1977/78. (Parasitic diseases recorded in reindeer during meat inspection in Kautokeino (Norway) in autumn and winter, 1977-1978). Norsk Vet.tidsskr. 1978, 90, 651-653.

Skjølaas, O.: Sarcosporidier i reinkjøtt i Kautokeino-området. (Sarcosporidia in reindeer meat in the Kautokeino-area). Norsk Vet.tidsskr. 1970, 82, 264-265.

Yakimoff, W. L.: Zur Frage der Sarcozysten der Rentiere. (Sarcocystosis in reindeer). Z. Infekt.-Kr. Haustiere 1936, 50, 217-223.

Yakımoff, W. L. \& I. I. Sokoloff: Die Sarcozysten des Renntieres und des Maral (Sarcocystis grüneri n. sp.) (Sarcocysts of the reindeer and maral). Berl. tierärztl. Wschr. 1934, 50, 772—774.

\section{SAMANDRAG}

Ei lysmikroskopisk samanlikning av cystene til fire Sarcocystis spp. hos tamrein $i$ Nord-Noreg.

Prøvar av skjelett- og hjertemuskulatur frå 12 tamreinar frå Finnmark vart unders $\varnothing \mathrm{kt}$ for sarcocyster under eit stereomikroskop. Cyster vart isolert og vidare unders $\emptyset \mathrm{kt}$ med omsyn til form, storleik og veggstruktur under eit lysmikroskop. Cyster av 4 arter vart identifisert.

S. rangiferi n. sp. hadde makroskopiske cyster som målte $2106 \times$ $403 \mu \mathrm{m}$. Dei vart berre påvist i skjelettmuskulaturen. Cysteveggen 
hadde tettsitjande, fingerliknande protrusjonar som målte $13.2 \times 6.7$ $\mu \mathrm{m}$. Cystene var omgjevne av eit fibrillært lag.

S. tarandi n. sp. hadde mikro- til makroskopiske cyster. Vanlegvis var berre skjelettmuskulaturen parasittert, men nokre få cyster vart påvist i eitt av dei unders $\varnothing$ kte hjerta. Cystene i skjelettmuskulaturen målte $999 \times 75 \mu \mathrm{m}$, og cysteveggen hadde tettsitjande, fingerliknande protrusjonar som målte $9.2 \times 2.2 \mu \mathrm{m}$. Cystene i hjertemuskulaturen var kortare og tjukkare.

S. grueneri hadde mikro- til makroskopiske cyster berre i hjertemuskulaturen. Cystene målte $581 \times 137 \mu \mathrm{m}$. Cysteveggen hadde ingen synlege protrusjonar.

Sarcocystis sp. hadde mikro- til makroskopiske cyster berre i skjelettmuskulaturen. Cystene målte $916 \times 64 \mu \mathrm{m}$. Cysteveggen hadde korte (under $1 \mu \mathrm{m}$ lange), halvkuleforma protrusjonar som knapt var synlege ved lysmikroskopi. Cyster av denna arta vart tidlegare rekna for å tilhøyra S. grueneri.

Ein har gjort framlegg om nye namn (S. rangiferi og S. tarandi) for 2 tidlegare namnlause Sarcocystis-arter hos rein.

\section{(Received April 6, 1984).}

Reprints may be requested from: B. Gjerde, the Norwegian College of Veterinary Medicine, Box 8146, Dep., N-0033 Oslo 1, Norway. 